\title{
Preliminary economic study of biodiesel production from pequi in Brazil
}

\begin{abstract}
This study deals with the economic feasibility of biodiesel production in Brazil by using the pequi oil as raw matter. The software SIMB-E was used during simulations in which a cash flow model related economic indexes with biodiesel production features. Competitiveness between selling prices of biodiesel and petro diesel, fixed capital costs, operating costs, depreciation, and auxiliary costs were also considered during the economic calculations. A total of 8 scenarios of production were simulated and 4 of them presented competitive biodiesel selling prices, being considered as worthwhile projects in the final analysis. But, all simulated scenarios were found to be potentially profitable and should be motivated considering sustainability, social and environmental aspects. The worthwhile projects were plants with alkaline transesterification, indicating that the success of biodiesel production from alternative raw matter still depends on incomes from the feedstock co-products and glycerol, as well as on the costs of catalyst and feedstock. Pequi contributed to the feasibility of biodiesel production due to its high yield, low costs of fruits and good valuation of its co-products.
\end{abstract}

Keywords: cash flow economic model, simulation, biofuel, transesterification, Caryocar brasiliense
Volume I Issue 5 - 2017

\section{Daniela de C Lopes, Antonio José Steidle Neto \\ Department of Agrarian Sciences, Federal University of São João} del-Rei, Brazil

Correspondence: Antonio José Steidle Neto, Department of Agrarian Sciences, Federal University of São João del-Rei, MG 424, km 47, Sete Lagoas, Minas Gerais, Zip Code 3570I-970, P.O. Box 56, Brazil,Tel 55 3I-3775-552I, Email antonio@ufsj.edu.br

Received: November 07, 2017 | Published: December 08 2017
Abbreviations: NVP, net present value; BCR, benefit-costs ratio; IRR, internal rate of return

\section{Introduction}

The demand for renewable energy use is continuously rising, since fossil fuels have been depleted and their extensive use has caused environmental issues, such as global warming. ${ }^{1}$ Among renewable energy options, Biofuel have attracted attention in part because they are liquid fuels that can be easily used in motor vehicles, and in some cases with little or no modification of existing gasoline or diesel fuel engines. ${ }^{2,3}$ Over the last decade, global Biofuel production increased rapidly. In 2008, about 15billion liters of biodiesel were produced globally. New projections indicate that the world biodiesel production tends to increase from 31 billion of liters in 2015 to 41.4billion liters in 2025. The United States is still the largest Biofuel producer, followed by Brazil and the European Union. While corn-based ethanol is dominating domestic production in the United States, Brazil produces ethanol mainly from sugar cane and Biofuel production of the European Union is mainly derived from canola and sunflower crops. ${ }^{4}$

Pequi (Caryocar brasiliense) is oil specie that can be used in biodiesel production. ${ }^{5}$ This tree is popularly known in southeastern, central western and northeastern regions of Brazil. It is one of the main species at the Brazilian Cerrado due to its use in culinary, popular medicine, industry in general, besides its potential for Biofuel production. The biodiesel from pequi oil and methanol through homogeneous alkaline catalysis reached a conversion of over $98 \%$, presenting sufficient quality according to the limits established by the Brazilian Petroleum National Agency. ${ }^{8}$ The average oil content of pequi pulp on mass basis is $30 \%$ and the potential yield of this crop is around of $3.7 \mathrm{t}$ ha- 1 year- $1{ }^{6,7}$ Besides technical, environmental and social aspects, economic feasibility is also of great importance to assess the biodiesel production viability. The choice of feedstock, chemicals and technology to employ in a production plant is based on such variables as local availability, cost, government support and quality of the resultant fuel. These choices will in turn influence costs, the biodiesel production viability and the biodiesel competitiveness with petro diesel. ${ }^{1-9}$ In this paper biodiesel production features are related with the economic indexes Net Present Value (NVP), BenefitCosts Ratio (BCR), Internal Rate of Return (IRR) and payback period through a model built up from cash flows and implemented in the software SIMB-E, which was specially developed for economic analysis of biodiesel production. ${ }^{10}$ This work should motivate the academic and industrial interest on pequi, allowing diversifying energy and agriculture activities. Also, it should guide choices regarding investment in biodiesel production.

\section{Materials and methods}

A total of 8 scenarios were simulated considering seed-oilprocessing and only oil-processing plants performing enzymatic and alkaline transesterifications of pequi oil with methanol and ethanol (Figure 1). All studied configurations were considered as continuous processes to meet an industrial design scale of biodiesel production. All simulated investments were analyzed for a period of $15 y e a r s$ (lifetime of project). (Table 1) the initial investments and operating costs used in simulations. The initial investment was estimated based on the capacity of the plant, the plant building, the equipment installation and technology applied, varying according to the different simulated scenarios ${ }^{11,12}$ Operating costs, such as cooling water, electricity, labor and other expenses were estimated according to the market and prices in Brazil. ${ }^{13-15}$ Annual costs of depreciation and maintenance were estimated at 10 and $1.5 \%$ of the capital investment, respectively. ${ }^{9}$ To calculate the cash flows, an inflation rate of $12.0 \%$ per annum and an attractiveness rate of $13 \%$ were used. Also, during comparisons, the petro diesel price was R\$3.20 perkg. ${ }^{8}$ Taxation of 
biodiesel was not considered since Law No. 12.546-2011 established the total exemption of the taxes PIS/PASEP and COFINS for biodiesel producers in Brazil. ${ }^{16}$

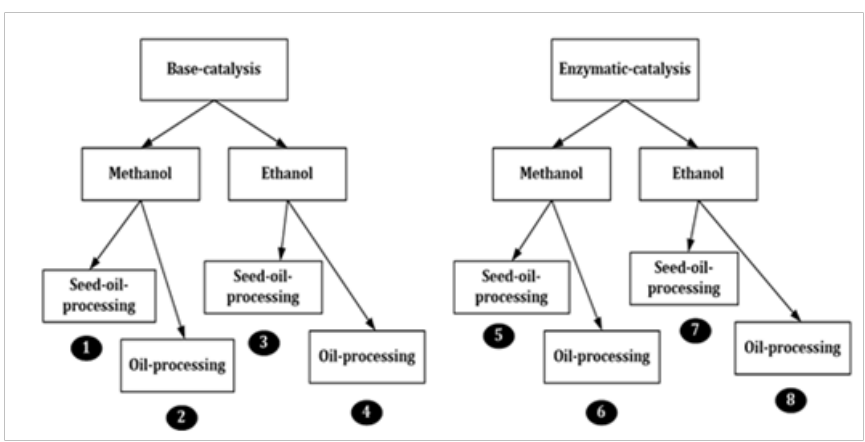

Figure I Simulated scenarios and their features.

Table I Simulated initial investments and operating costs

\begin{tabular}{lll}
\hline Scenario & Capital investment $(\mathbf{R} \$)$ & Operating costs (R\$Year- $\mathbf{)})$ \\
\hline 1 & $4,500,000.00$ & $585,000.00$ \\
2 & $1,500,000.00$ & $195,000.00$ \\
3 & $4,050,000.00$ & $1,134,000.00$ \\
4 & $1,350,000.00$ & $378,000.00$ \\
5 & $4,950,000.00$ & $643,500.00$ \\
6 & $1,650,000.00$ & $214,500.00$ \\
7 & $4,500,000.00$ & $1,260,000.00$ \\
8 & $1,500,000.00$ & $420,000.00$ \\
\hline
\end{tabular}

Simulations included the production and sale of partially pure glycerol co-product. When seed-oil-processing plants were considered, the pequi meal was also included as a co-product. The amount of feedstock, catalyst, alcohol and co-products were calculated by stoichiometry, considering the molar ratio of triglycerides to alcohol (1:6 or 1:3 depending on the catalyst), the molar ratio of triglycerides to esters $(1: 3)$, and the molar ratio of triglycerides to glycerol (1:1). The prices of feedstock, alcohol, catalyst and co-products are shown in (Table 2) and were considered according to the market in Brazil. ${ }^{11-18}$ During simulations the annual production capacity of plants was assumed to be 15,000 ton with utilization ratio of $95 \%$. In simulations where alkaline catalysts were used in transesterifications, the molar ratio of alcohol to triglycerides was $6: 1$. For enzymatic catalysis this ratio was $3: 1 .{ }^{19}$ The alkaline and enzymatic catalyst concentrations of 1.5 and $4 \%$ by weight of oil, respectively, were used considering yields from 95 to $98 \%$ conversion of oil into esters. ${ }^{19,20}$ It was also accounted the enzyme reuse, considering that immobilized enzyme operates over 30 days without losing catalytic activity. ${ }^{21}$ Oil content and molar weight of pequi oil were assumed to be $50 \%$ and $1,171.1 \mathrm{~g}$ mol$1 .{ }^{22,23}$ Molecular weight of biodiesel from pequi was $390.4 \mathrm{~g} \mathrm{~mol}-1 .{ }^{24}$ Molecular weights of ethanol, methanol and glycerol were 46, 32 and $92 \mathrm{~g}$ mol-1, respectively. ${ }^{25,26}$

For all scenarios different profit margins were tested and those values in which the economic feasibility was verified with minimal biodiesel prices were considered during the final analysis (Table 3). Simulations were carried out using the SIMB-E tool, specially developed for this purpose, which is based on a cash flow model and considers the main costs related with the biodiesel production and economic indexes. ${ }^{10}$ The cash flow is the balance of the amount of revenues and the expenses during the lifetime of the project, considering the year zero without revenues and with the capital investment as expenses. Cash flow data are used in SIMB-E to calculate the economic indexes net present value (NVP), benefit-costs ratio (BCR), internal rate of return (IRR) and payback period. The two first indexes are calculated as

$$
\begin{aligned}
& N_{p}=\sum_{i=1}^{L} \frac{C_{f}^{i}}{(1+k)^{i}}-C \\
& B_{c}=\left(\sum_{i=1}^{L} \frac{C_{f}^{i}}{(1+k)^{i}}\right) / C
\end{aligned}
$$

Table 2 Raw materials and co-products prices

\begin{tabular}{ll}
\hline Item & Cost $\left(\mathbf{R} \$\right.$ Ton $\left.^{-1}\right)$ \\
\hline Pequi crude oil & $2,250.00$ \\
Pequi fruits & 800 \\
Methanol & 403 \\
Ethanol & $1,340.00$ \\
Base & $1,135.84$ \\
Enzyme & $91,600.00$ \\
Pequi meal & $3,000.00$ \\
Glycerol & $2,473.20$
\end{tabular}

Table 3 Simulated scenarios and their profit margins

\begin{tabular}{ll}
\hline Scenario & Profit margin (\%) \\
\hline 1 & 60 \\
2 & 5 \\
3 & 30 \\
4 & 5 \\
5 & 5 \\
6 & 5 \\
7 & 5 \\
8 & 5
\end{tabular}

where $\mathrm{C}$ is the capital cost $(\mathrm{R} \$), \mathrm{i}$ is the year considered in the cash flow (varying from 1 to the lifetime of the project), $\mathrm{C}_{\mathrm{f}}$ is the balance of the amount of revenues and expenses (R\$), $\mathrm{k}$ is the annual inflation rate (\%), $\mathrm{N}_{\mathrm{vp}}$ is the net present value $(\mathrm{R} \$), \mathrm{B}_{\mathrm{cr}}$ is the BenefitCosts Ratio and $\mathrm{L}$ is the lifetime of the project (years). The payback period is estimated based on the NVP value, considering the number of months in which the investment in the biodiesel plant will be recovered. The IRR is calculated by Langrange interpolation in an iterative process that searches the rate at which the project returns a NPV of zero. Further, the selling price of biodiesel is estimated based on the production features and evaluated as one of the variables that influence the economic feasibility. Biodiesel production will be economically viable if the NPV is greater than zero, the BCR is greater than one, the payback period is smaller than the lifetime of 
the project and the IRR is greater than the attractiveness rate. These conditions indicate that the investment would be profitable. But, this viability should be prejudiced if the selling price of biodiesel does not be competitive with petro diesel. In this case, the project will be considered economically viable, but risky.

\section{Results and discussion}

All the 8 scenarios were evaluated and compared considering economic indexes and selling prices of biodiesel. The IRR of scenario 5 did not converged, presenting an extremely high value. Thus this scenario was not evaluated regarding IRR. Considering the other scenarios, all IRRs presented values above the attractiveness rate of $13 \%$ (Figure 2). According to this index, all scenarios presented potential to economic feasibility, since the IRR refers to the return which can be earned on the capital invested in the project. That is, it represents the interest rate that makes the present value of a cash flow equal to zero and should be greater than the attractiveness rate to a project be economically feasible. The attractiveness rate for it time describes perceived quality and utility of a product. The high values observed for scenarios 1 and 3 should be explained by their configurations which combined seed-oil processing and alkaline catalysis. This resulted in lower expenses with inputs and more profits with the co-products selling. Also, these scenarios were simulated with greatest profit margins. High values were also observed for scenarios 6 and 7 and should be explained since these scenarios were those with smallest capital investments and operational costs when using enzymatic catalysis. The simulated IRRs agreed with those presented by Vlysidis et al. ${ }^{1}$ Marchetti. ${ }^{27,28}$

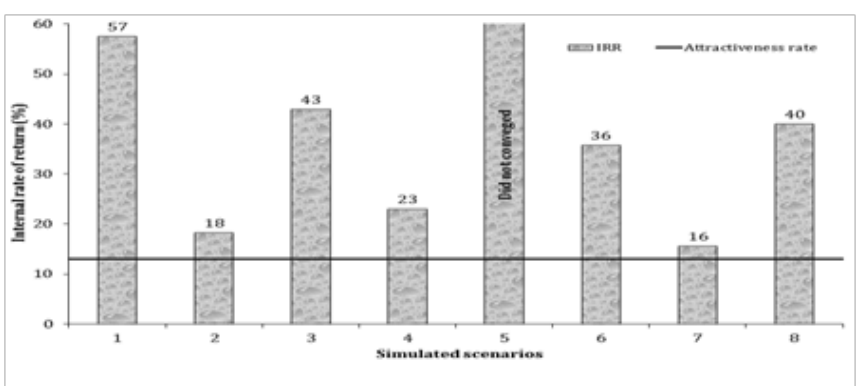

Figure 2 Internal rates of return (IRR) and attractiveness rate for the simulated scenarios.

Simulated scenarios maintained economic potentiality when analyzing the payback period (Figure 3), since all of them presented values smaller than the lifetime of project (15years). The simulated payback periods agreed with those obtained by Vlysidis et al. ${ }^{1-28}$ Probably, the greatest payback periods observed for scenarios 5 and 7 are associated with the required capital investments of these configurations, which are based on enzymatic catalysis and seed-oil processing plants. In these cases, even considering the co-product incomes, the input expenses and the operational costs should have contributed to a higher time for return of the capital investment. (Figure 4) presents the BCRs of all simulated scenarios. These values varied from 1 to 5 , showing that sum of benefits exceeded or equaled the costs in all simulations. A BCR of 1 is the minimum value for such a project to be considered profitable. The BCRs found in this work agreed with the results obtained by Carvalho et al ${ }^{14-28}$ but the scenarios 2, 4, 5 and 7 were very near of the feasibility limit. On the other hand, scenarios 1, 3, 6 and 8 detached among the other as the most profitable ones.

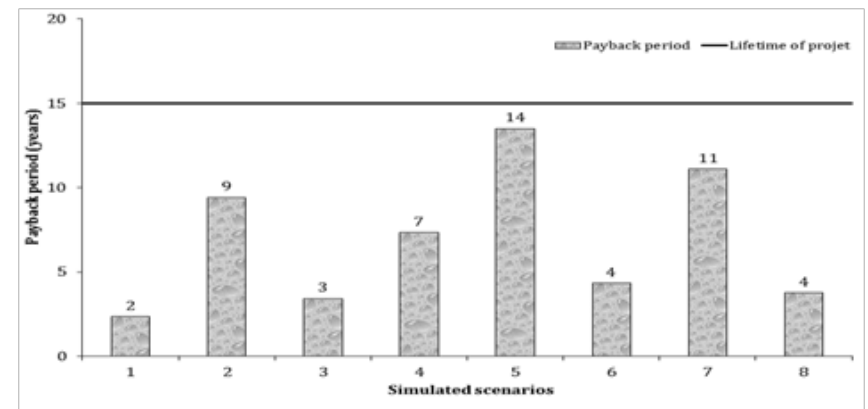

Figure 3 Payback period and project lifetime for the simulated scenarios.

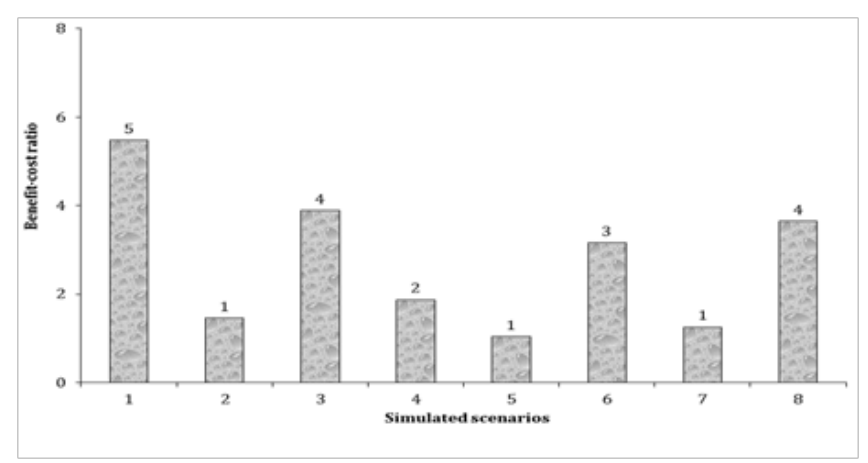

Figure 4 Benefit-cost ratios (BCR) for the simulated scenarios.

All simulated scenarios presented NPV greater than zero, also indicating potentially feasible projects (Figure 5). The simulated NPVs agreed with those found by Vlysidis et al. ${ }^{1-28}$ Once again, scenario 5 was prejudiced by the high capital investment, as well as by the high input expenses and operational costs. For this, probably the co-product incomes and biodiesel selling prices were not capable of suitably compensating the production costs associated with this arrangement. Contrarily, scenario 1 was benefited by the lower operational costs, the high profit margin and the incomes from the feedstock co-products and glycerol, appearing as the more profitable configuration. Simulated NPVs represented the profit of the biodiesel production for 15 years by considering the time value of money. This index is the total sum of the capital expenditure, operating expenses and income generated by the project, discounted inflation rate to the initial moment of the lifetime. NPV is used as a long-term metric that requires information about rate of return, regulatory and market possibilities, and hedging options. For this, it is considered the more accurate index for an economic decision.

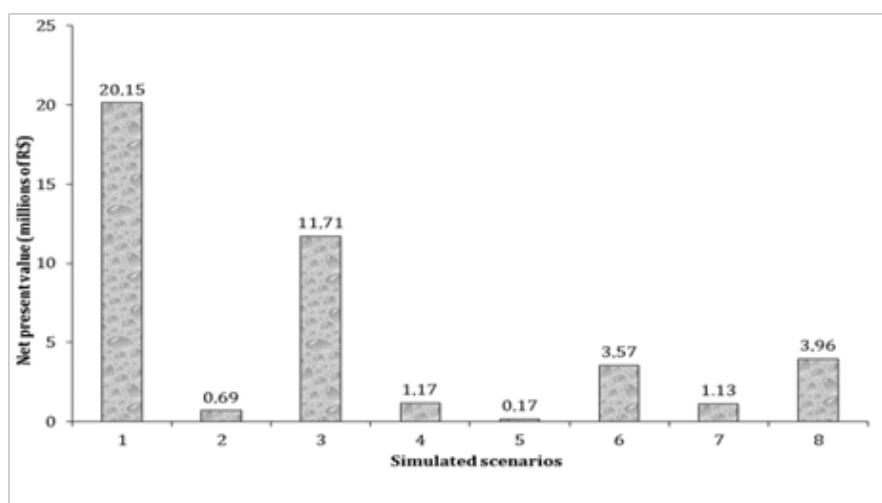

Figure 5 Net Present Values (NPV) for the simulated scenarios. 
As mentioned above, despite the feasibility confirmed by economic indexes, the selling price of biodiesel should be competitive with the conventional diesel one, since projects should be suitable and not risky. These values are generally ruled by international offer and demand of fuels, government policies and international agreements. Considering this parameter, only scenarios from 1 to 4 presented selling prices of biodiesel smaller than the petro diesel one (Figure 6). These scenarios represented projects with alkaline catalysis being considered worthwhile in final analysis found only 2 feasible and not risk scenarios when performing a similar economic analysis for macauba biodiesel, which were seed-oil plants with alkaline transesterification. The greater number of worthwhile projects verified in this study can be justified considering that the petro diesel prices considerably increased in Brazil from 2013. Incomes from pequi meal and glycerol were also fundamental to achieving the competitive biodiesel prices and economic indexes in scenarios with alkaline catalysis. Glycerol selling represented a minor impact on the total biodiesel production costs when compared with the cost of pequi meal. According to Macedo et al. ${ }^{29}$ pequi meal is valorized due to its composition, particularly its high starch content, which warrants the evaluation of its potential also as a feedstock for ethanol production. Moreover, the solid residue coming from the fermentation process has a huge potential as a protein source for use in animal feed.

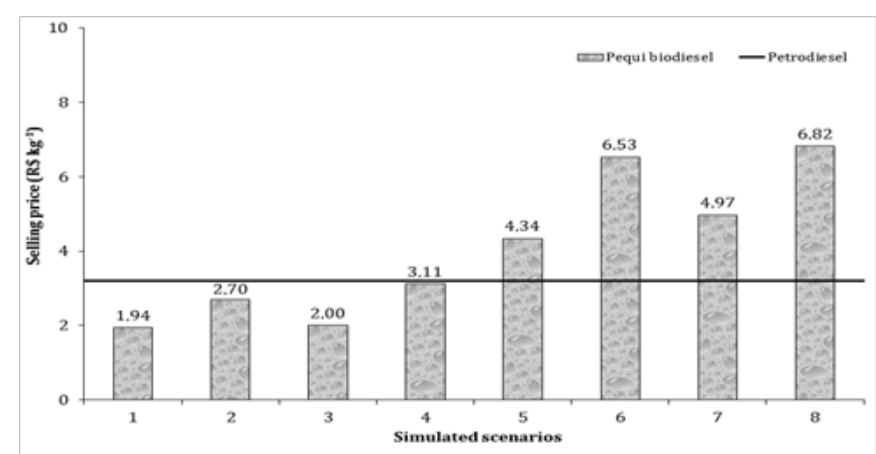

Figure 6 Selling prices of pequi biodiesel and petrodiesel obtained during simulations.

Fu Seed-oil-processing and alkaline transesterifications (scenarios 1 and 3) were additionally benefited by the low costs of catalyst and feedstock. The crude oil of pequi is around 2.8 times more expensive than their fruits and the enzymes are approximately 80times more expensive than the bases. These high costs also contributed to minimizing the influence of the alcohol on the selling price of biodiesel. Comparing scenarios where only processing type varied, differences on selling prices of biodiesel produced from pequi varied from $\mathrm{R} \$ 0.76$ to $2.19 \mathrm{per} \mathrm{kg}$. These results agree with the discussed by Amigun et al. ${ }^{9}$ where it is affirmed that seed-oil-processing plants may provide logistic advantages in that the feedstock can be used at source, reducing costs to an oil processing plant. Other observation is that the increased cost of production due to higher unit capital cost should be more than offset by savings in transportation cost. As mentioned above, the difference between methanol and ethanol prices did not have significant influence on biodiesel prices when compared with other production variables. The maximum difference observed in the selling price of biodiesel was of $\mathrm{R} \$ 0.63$ per $\mathrm{kg}$ when comparing scenarios where only the alcohol varied. In Brazil the ethanol cost is around three times the methanol one.

For this, methanol is still the most commonly used alcohol in commercial biodiesel plants. However, it is important to motivate the development of technologies and policies that encourage the use of ethanol and contribute to decrease its costs. As discussed by Harding et al. ${ }^{19-25}$ ethanol is renewable and has suggested advantages due to being environmentally based and carbon dioxide neutral, making it the most promising alternative for producing biodiesel. Regarding enzymatic transesterification, it was confirmed that the main obstacle for its commercialization is the cost of the enzyme, mainly when this cost is compared with alkaline-catalyzed processes. Since considering that enzyme should be reused during 30days without losing catalytic activity, its cost was considerably greater than the base one, reflecting on the selling prices of biodiesel. Enzymatic transesterifications resulted in selling prices of biodiesel from pequi around 3.2times greater than those produced from alkaline catalysts. Other challenges associated with enzymatic transesterification include low reaction rates and the potential for enzyme deactivation. It is a concern that these advances should contribute to decrease this catalyst price. ${ }^{1-21}$ The increasing interest in enzymatic transesterification is justified by several factors. Among them, enzymes perform their catalytic activity in more gentle conditions and with a variety of triglyceride substrates, including waste oils and fats with high levels of FFA. Furthermore, biodiesel separation and purification are much easier, resulting in a more environmentally friendly process. ${ }^{30}$

Finally, alternative crops should contribute to the feasibility of biodiesel production due to its costs and co-products. Specifically, pequi is a tree widespread throughout the Cerrado in Brazil, which sale is significant at the harvesting time by families living in rural communities, contributing to family income in these communities. Its high yield, low costs of fruits and good valuation of its co-products were essential to reach the economic potentiality of all simulated scenarios, as well as, the competitive selling prices of biodiesel in the worthwhile scenarios. However, pequi fruits have been collected by decades in wild explorations areas. Although some domestication initiatives have already been initiated, they are in experimental stages. ${ }^{31}$ Thus, studies and policies about the management of this species in relation to sustaining yield should be motivated. It's important to emphasize that the rational extractivism of native trees should represent a good alternative in order to promote a sustainable occupation, as well as social and economic development, since the transesterification of several vegetable oils, resultants of agricultural activities and the extractive sector, appears as a technological alternative. Also, the traditional use of this crop for food purposes raises discussions about the competition with a non-food use. These facts have been contributed to the little interest of the biodiesel industry in this feedstock.

\section{Conclusion}

All the 8 simulated scenarios were potentially profitable, resulting in attractive economic indexes. But, among them, 4 presented competitive biodiesel selling prices being considered as worthwhile projects. Biodiesel plants with integrated oil mill and alkaline transesterification presented more attractive IRRs, NPVs, BCRs, payback periods, and biodiesel prices, followed by those with oilprocessing and alkaline transesterification. Considering the pequi biodiesel, incomes from its co-products and glycerol combined with the lower costs of alkaline catalyst and feedstock were crucial to achieve competitive biodiesel prices. Yet, the rational extractivism of pequi should represent a good alternative to promote a sustainable occupation with social and economic development in Brazil, also contributing to the increase of the commercial importance of this tree. However, the conflict between food and non-food use of this crop is an 
obstacle for pequi biodiesel production. This study can be extrapolated to other technologies, market scenarios or feedstock as a mean to show tendencies of how relevant variables can affect a biodiesel plant and to search for ways to decrease costs and make this kind of production more competitive in the market. Simulations discussed in this paper are for research purpose only. For recommendations and decisions about specific projects please contact the authors.

\section{Acknowledgements}

The authors would like to thank the Conselho Nacional de Desenvolvimento Científico e Tecnológico $(\mathrm{CNPq})$ for its financial support.

\section{Conflict of interest}

Author declares that there is no conflict of interest.

\section{References}

1. Vlysidis A, Binns M, Webb C, Theodoropoulos C. A techno-economic analysis of biodiesel biorefineries: assessment of integrated designs for the co-production of fuels and chemicals. Energy. 2011;36:4671-4683.

2. Balat M. Potential alternatives to edible oils for biodiesel production-a review of current work. Energy Conversion and Management. 2011;52(2):1479-1492.

3. Jaeger W, Egelkraut TM. Biofuel economics in a setting of multiple objectives and unintended consequences. Renewable and Sustainable Energy Reviews. 2011;15(9):4320-4333.

4. OECD/FAO. Biofuels. OECD-FAO Agricultural Outlook 2016-2025. OECD Publishing, Paris, France; 2016. p. 116-132.

5. Demirbas A. Progress and recent trends in biodiesel fuels. Energy Conversion and Management. 2009;50(1):14-34.

6. Oliveira MEB, Guerra NB, Barros LM, et al. Agronomic and quality aspects of pequi (Aspectos agronômicos e de qualidade do pequi). EMBRAPA, Brazil; 2008. p. 1-32.

7. Roesler R, Cathariono RR, Malta LG, et al. Antioxidant activity of Caryocar brasiliense (pequi) and characterization of components by electrospray ionization mass spectrometry. Food Chemistry. 2008;110(3):711-717.

8. ANP. Levantamento de preços e Legislação sobre biocombustíveis, Agência Nacional do Petróleo. Brazil; 2017.

9. Amigun B, Müller Langer F, von Blottnitz H. Predicting the costs of biodiesel production in Africa: learning from Germany. Energy for Sustainable Development. 2008;12(1):5-21.

10. Lopes DC, Steidle Neto AJ, Martins PAR. Economic simulation of biodiesel production: SIMB-E tool. Energy Economics. 2011;33:1138-1145

11. Petrobrás. Energia e Tecnologia-Biocombustíveis. Brazil; 2017.

12. BNDES. Investimentos em biodiesel. Banco Nacional do Desenvolvimento. Brazil; 2017.

13. Cruz RP, Ferreira FB, Rodriguez FA. Simulação e análise econômica da produção de biodiesel a partir de óleo de macaúba. The Journal of Engineering and Exact Sciences. 2017;3(3):53-560.
14. Carvalho F, Lirio V, Moura A. Viabilidade econômica do biodiesel em Mato Grosso. Revista de Política Agrícola. 2011;20(1):39-51.

15. Martins SF, Cervi, RG. Análise de viabilidade econômica da construção de uma micro usina de biodiesel utilizando material de sucata e reciclagem. Tekne e Logos. 2012;3(3):1-11.

16. MME. Ministério de Minas e Energia. Brazil; 2017.

17. Conab. Companhia Nacional de Abastecimento, Brazil; 2017.

18. Distriol. Distriol Comércio de Insumos. Brazil; 2017.

19. Harding KG, Dennis JS, von Blottnitz H, et al. A life-cycle comparison between inorganic and biologic catalysis for the production of biodiesel. Journal of Cleaner Production. 2007;16(13):1368-1378.

20. Bernardes OL, Bevilaqua JV, Leal MC, et al. Biodiesel fuel production by transesterification reaction of soybean oil using immobilized lipase. Applied Biochemical and Biotechnology. 2007;137-140(1-12):105-114.

21. Chen HC, Ju HY, Wu TT, et al. Continuous production of lipase-catalyzed biodiesel in a packed-bed reactor: optimization and enzyme reuse study. Journal of Biomedicine and Biotechnology, ID 950725. 2011. p. 6.

22. Lima A, Silva AMO, Trindade RA, et al. Composição química compostos bioativos presentes na polpa e na amêndoa do pequi (Caryocar brasiliense Camb.). Revista Brasileira de Fruticultura. 2007;29(3):695-698.

23. Deus TN. Extração e caracterização de óleo de pequi (Caryocar brasiliense Camb.) para usos sustentáveis em formulações cosméticas óleo/água $(O / A)$. Master Degree thesis. Pontifícia Universidade Católica de Goiás, 2008. p. 1-75.

24. Gondra ZA. Study of factors influencing the quality and yield of biodiesel produced by transesterification of vegetable oils. Master Degree thesis. University of Gavle, Sweden; 2010. p. 1-112.

25. Arzamendi G, Arguinarena E, Campo I, et al. Monitoring of biodiesel production: simultaneous analysis of the transesterification products using size-exclusion chromatography. Chemical Engineering Journal. 2006;122(1-2):31-40

26. Agarwal AK. Biofuels (alcohols and biodiesel) applications as fuels for internal combustion engines. Progress in Energy and Combustion Science. 2007;33(3):233-271.

27. Marchetti JM. The effect of economic variables over a biodiesel production plant. Energy Conversion and Management. 2011;52(10):3227-3233.

28. Lopes DC, Steidle Neto AJ, Mendes AA, et al. Economic feasibility of biodiesel production from Macauba in Brazil. Energy Economics. 2013;40(C):819-824.

29. Macedo AL, Santos RS, Pantoja L, et al. Pequi cake composition, hydrolysis and fermentation to bioethanol. Brazilian Journal of Chemical Engineering. 2011;28(1):9-15.

30. Gog A, Roman M, Tosa M, et al. Biodiesel production using enzymatic transesterification-current state and perspectives. Renewable Energy. 2012;39(1):10-16.

31. Zardo RN, Henriques RPB. Growth and fruit production of the tree Caryocar brasiliense in the Cerrado of central Brazil. Agroforest Science. 2011;82:15-23. 